\title{
小型試験体による木造断熱壁体の防火性能予測に関する研究
}

\author{
ロックウール断熱材を用いた各種断熱工法の準耐火性能の予測可能性の検討
}

\section{STUDY ON THE PREDICTION OF THE FIRE PROTECTION PERFORMANCE OF INSULATED WOODEN-WALLS BY SMALL-SCALE SPECIMENS}

Predictability of quasi-fireproof performance of external wooden walls with rock-wool insulation

\author{
糸毛 治*, 長谷見 雄二**, 月 館 司***, 鈴 木大隆*** \\ Osamu ITOGE, Yuji HASEMI, Tsukasa TSUKIDATE \\ and Hirotaka SUZUKI
}

\begin{abstract}
For the establishment of rational prediction of the fire protection performance of insulated wooden walls, a series of small scale furnace tests are conducted on various types of wall constructions with rock-wool insulation, the most stable practical insulation material. The tests suggest practical predictability of the temperature profile by one-dimensional steady-state heat transfer calculation for walls without cavity, importance of cavity for the fire protection performance of insulated walls, potential predictability of the mechanical integrity from the back-surface temperature of the protection layer.
\end{abstract}

Keywords : Wooden wall, Rock-wool-insulation, Constructing method on Insulated wall, Fire Protection Performance, Small-scale Specimens, One-dimensional Steady-state heat transfer Calculation. 木造壁体，ロックウール断熱材，断熱工法，防火性能，小型試験体，一次元定常熱伝導計算

\section{1. はじめに}

木造外壁の壁体構成は、使用される外装材の他、断熱材や断熱工 法によって多岐にわたる。しかし、それら断熱材や断熱工法が及ぼ す防火性能への影響は系統的には把握できていないため、防火性能 を必要とする木造断熱壁体の開発や防火性能評価には多数の実大規 模の試験体を用いた載荷加熱試験 (以下、実大試験) が必要である。 そのため、製品開発にかかる費用と時間が膨大になるだけでなく、 大規模な試験装置のない地域での技術開発を困難にし、結果的に部 材開発上の障害になっている。この負担を軽減するためには、断熱 工法ごとに断熱材の種類・設置位置や厚さ、他の要素材料が防火性 能へ及ぼす影響を系統的に明らかにして、少数の仕様に関する実大 試験から断熱工法や細部の条件が異なる他の仕様の防火性能を類推 できたり、実大試験の実施前に壁体の構成や断熱仕様から計算にて 防火性能の見通しが予め得られたりすることが望ましい。

本研究は、断熱仕様の内容が木造断熱外壁の防火性能に及ぼす影 響の基本的傾向を、壁断面方向の寸法を再現する小規模試験体（以 下、小型試験体）による実験で検討することを通じて、木造断熱外 壁の開発における実大試験への依存を軽減する知見を誘導するとと もに、小型試験体による実験の限界についても改めて検討しようと するものである。

本研究で対象とする軸組構法では、建築基準法上、外壁の防火性
能を構成する遮炎性、遮熱性、非損傷性のうち、非損傷性は最終的 には柱の座屈に支配されるため、小型試験体では評価できないが、 外壁柱の重要な座屈要因である柱の断面性能の低下については、小 型試験体による実験でも加熱条件を再現できれば把握できる可能性 がある。一方、柱の変形が小さく遮炎性、遮熱性が外壁の防火性能 の主要因となる場合は、加熱に伴う壁の力学的変形は大きくならな いことが想定される。そこで、遮炎性、遮熱性は壁体内の伝熱と壁 を構成する面材の温度上昇による亀裂・溶融等に支配されると考え られ、内外装面材の目地等、断熱方向の伝熱を不均一化する要因の 影響を除けば、断面を再現する小型試験体で把握できよう。

一方、外壁に使われる断熱材は無機材料から高分子材料まで多様 であり、高温で溶融・燃焼する材料もある。外壁の断熱工法の設計 条件と防火性能の関係を系統的に把握し、設計仕様に関する防火性 能の予想を容易にする第一歩として、火㷋加熱中に断熱材が溶融・ 燃焼しない場合の防火性能の予測可能性を検討するために、本研究 では、実用的な断熱材の中では不燃性で高温での熱変性が最も小さ いロックウール断熱材を対象とする注 1), 1)。

\section{2. 実験概要}

(1) 試験体概要

試験体は、木造壁体の典型的な構成として、外装材を不燃面材、

\footnotetext{
* 北海道立総合研究機構北方建築総合研究所 修士 (工学)

** 早稲田大学理工学術院 教授.工博

Hokkaido Research Organization, Northern Regional Building Research Institute, M.Eng.

** 北海道立総合研究機構北方建築総合研究所 博士 (工学) 
内装材をせっこうボードとする乾式工法の木製軸組造外壁の代表的 な断熱工法を網羅するように設計し、試験体の大きさは、幅 $800 \mathrm{~mm}$ ×高さ $800 \mathrm{~mm}$ （加熱面：幅 $600 \mathrm{~mm} \times$ 高さ $600 \mathrm{~mm}$ ）とした（図 1 ）。

木造壁体は、 45 分準耐火構造と 60 分準耐火構造の両方を想定し た。試験体は内装材以外の構成材料は変えずに、内装材の仕様を 45 分準耐火構造の場合は厚さ $15 \mathrm{~mm}$ のっこうボード注2)、60 分淮耐火 構造の場合は厚さ $15 \mathrm{~mm}$ の強化せっこうボード注3)とした。

検討対象とするロックウール断熱工法は、充てん断熱工法、外張 断熱工法、付加断熱工法の 3 種類 2) とし、比較のため無断熱壁体を 加えた。さらに外張断熱工法・付加断熱工法では、外張（付加）断 熱材の厚さを 2 通りとした（図 1 )。試験体に用いるロックウール 断熱材は住宅用断熱材として一般的に流通するものとし、充てん断 熱材には袋入りロッククール $32 \mathrm{~K} \sim 35 \mathrm{~K}$ 品を、外張（付加）断熱材 にはロックウール板（フェルト状のもの）40K 品を選定した。

なお加熱実験にあたっては、試験体に、加熱面の外縁部（幅 100

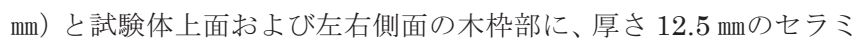
ックウールブランケットを張り付けた。

(2) 実験方法

加熱実験は、小型炬（装置 : 幅 $1,360 \mathrm{~mm} \times$ 高さ $1,315 \mathrm{~mm} \times$ 奥行き
$1,045 \mathrm{~mm}$ 、炉内寸 : 幅 $600 \mathrm{~mm} \times$ 高さ $600 \mathrm{~mm} \times$ 奥行き $810 \mathrm{~mm} ）$ に試験 体を設置して行った。試験体には載荷せずに、炉内温度を試験体表 面から $100 \mathrm{~mm}$ の位置で $\phi 3.2 \mathrm{~mm}$ のシース熱電対（K 熱電対）により 測定し、ISO834 加熱曲線に沿って加熱した。加熱時間は、試験体 仕様に合わせてそれぞれ、45 分準耐火構造仕様の場合は 45 分、60 分準耐火構造仕椂の場合は 60 分とした。

また加熱実験は、1つの試験体仕様につき、屋外側加熱試験（以 下、屋外加熱）と屋内側加熱試験（以下、屋内加熱）の両方を行っ た。ただし外張断熱工法・付加断熱工法では、屋外加熱を外張（付 加）断熱材が薄い場合のみ実施し、厚い場合は省略した。

(3) 測定項目

\section{1) 遮熱性・遮炎性に関係する要因の測定}

遮熱性・遮炎性に影響する要因の把握を目的として、遮熱性の判

\begin{tabular}{|c|c|}
\hline $\begin{array}{l}\text { (加熱側) } 1 \\
\text { 炭化部分 } \\
\text { (非加熱側) }\end{array}$ & 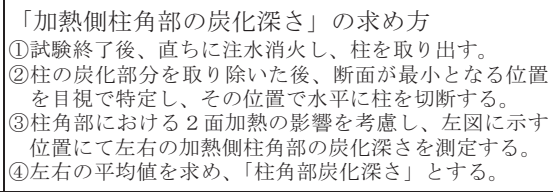 \\
\hline
\end{tabular}

図 2 「加熱側柱角部の炭化深さ」の求め方

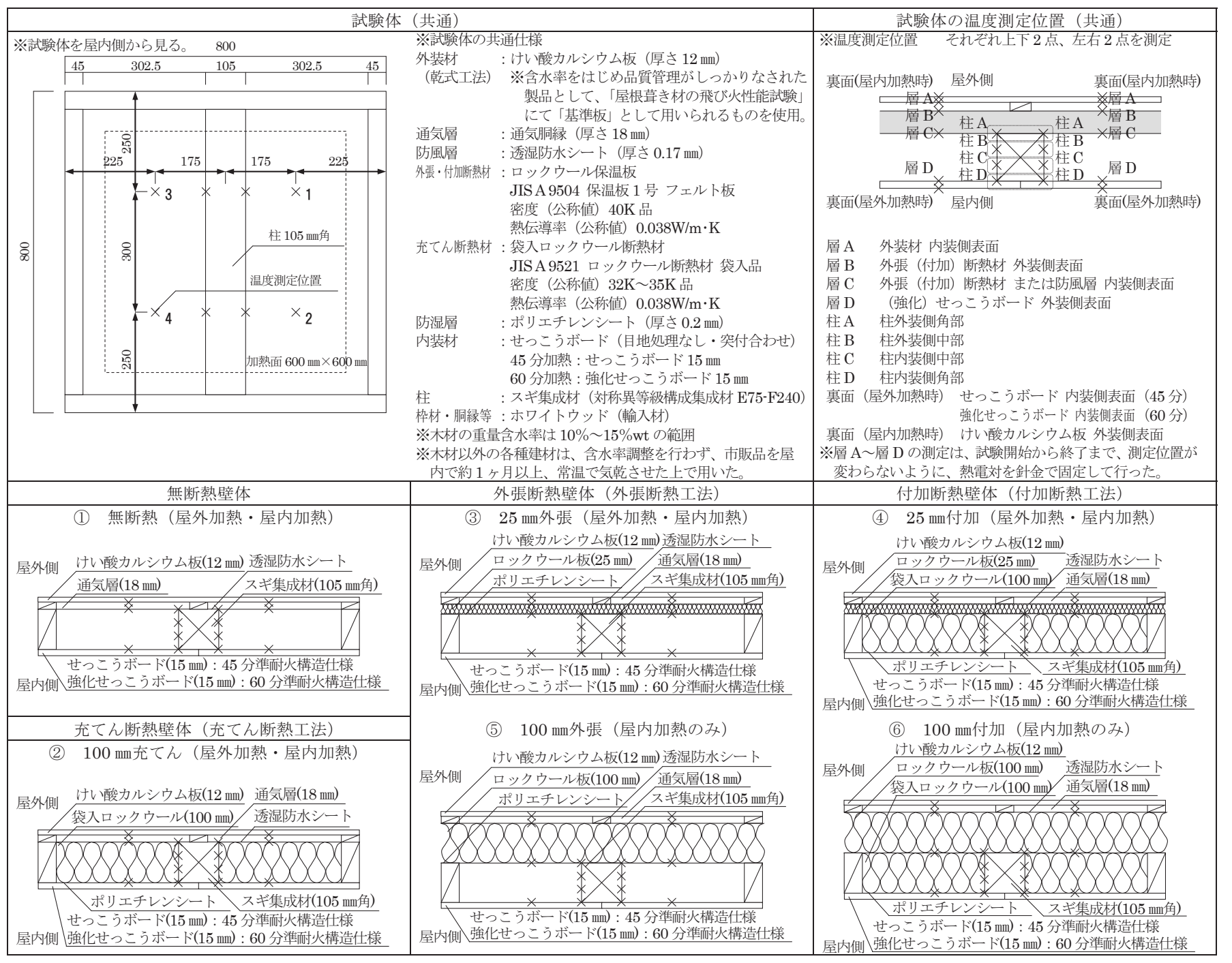

図 1 試験体概要と断熱工法ごとの試験体仕様 
定指標 ${ }^{3)}$ である試験体裏面温度の他、図 1 中に示す温度測定位置 $(\times$ 印）に K タイプ（CA）熱電対を設置して各構成材料の表面温度を 測定した。なお、遮炎性は、非加熱側からの目視により確認した。

\section{2) 非損傷性に関係する要因の測定}

非損傷性は小型試験体では直接把握できないが、軸組工法では柱 の断面の損傷に支配されると考えられる。そこで図 1 中に示寸位置 に熱電対を設置して柱側面の表面付近温度を測定した。標準火災加 熱時の柱の加熱状況を把握するとともに、柱の座屈に関わる指標と して 45 分、 60 分加熱後の柱の損傷の程度を次のように把握した。

柱の損傷は、試験終了後、最も炭化が進んでいる部分を目視で確 認して、断面寸法が最も小さい部分（以下、最小断面）を特定した。 この最小断面について断面積（試験前を $100 \%$ とした時の残存割合） と断面二次モーメントを求め、さらに前報 1)および既往研究 ${ }^{4)}$ に従 い、加熱側柱角部（加熱面に近い柱の隅角部を指す。屋外加熱時は 柱外装側角部、屋内加熱時は柱内装側角部が該当する。）の炭化深さ

\section{(図 2 ) を求めた。}

オイラーの座屈式 5)より材の支点間距離、端部条件、座屈長さが 同じであれば、座屈荷重は曲げ剛性（EI）に比例する。ここで実大 試験を想定して、ヤング係数を一定 $\left(\mathrm{E}=7.5 \mathrm{kN} / \mathrm{mm}^{2}{ }^{2}\right)$ 、柱の座屈長さ を $3,200 \mathrm{~mm}$ （柱の有効細長比 100 以上）と仮定すると、座屈荷重は 断面二次モーメント（I）に比例する。つまり柱の損傷が進むと、柱 の断面二次モーメントが小さくなり、座屈荷重も小さくなる。そこ で柱の損傷の程度を示寸指標として、断面二次モーメントの減少分 を柱の損傷度と定義し、試験前の柱の断面二次モーメント（I=10.1 $\left.\times 10^{7} \mathrm{~mm} 4\right)$ を柱の損傷度 $0 \%$ 、座屈荷重が想定される実大試験時の 載荷荷重と等しくなる時の柱の断面二次モーメント $\left(\mathrm{I}=2.65 \times 10^{6}\right.$ $\mathrm{mm}{ }^{4}$ ) を柱の損傷度 $100 \%$ 注 4 ) とし、最小断面の断面二次モーメント に対し、この 2 点間で線形補間した值をパーセント表示した。なお、 木材のヤング係数は温度の影響を受けるが、本実験では木材内部の 温度分布の測定には至っていないため、材の力学的性能の温度依存 性を考慮しない範囲で、断熱工法の種別・加熱方向と非損傷性の関 係を検討する。

\section{3. 試験体内部温度分布とその実用的予測可能性に関する考察 (1) 試験結果 (45 分加熱と 60 分加熱)}

45 分加熱および 60 分加熱の各層の温度推移を図 3 に示す。 45 分 準耐火構造と 60 分準耐火構造の場合で、試験体は内装材であるせ っこうボードの仕様は異なるが、断熱仕様、加熱方向ごとに両者の 実験結果を比較すると、45 分加熱における各層の温度推移は、60 分加熱における 45 分までの各層の温度推移といずれもほぼ合致し た（図 3 ）。特に屋内加熱では、すべての試験体で共通して、せっこ うボードが火災加熱を受け、せっこうボード外装側（非加熱側）表 面の温度が $100^{\circ} \mathrm{C}$ 付近になると温度停滞が生じた。この温度停滞の 間、せっこうボードより非加熱側に位置する各層や柱は温度上昇を 抑制される。45 分加熱、60 分加熱ともに $100^{\circ} \mathrm{C}$ 付近での温度停滞 は、試験開始 20 分頃まで続き、ほぼ同じ停滞時間となった注5)。

以上より、以降、壁体内の温度推移に着目し考察する場合には、 60 分加熱の試験結果を代表的に用いて論を進めていく。

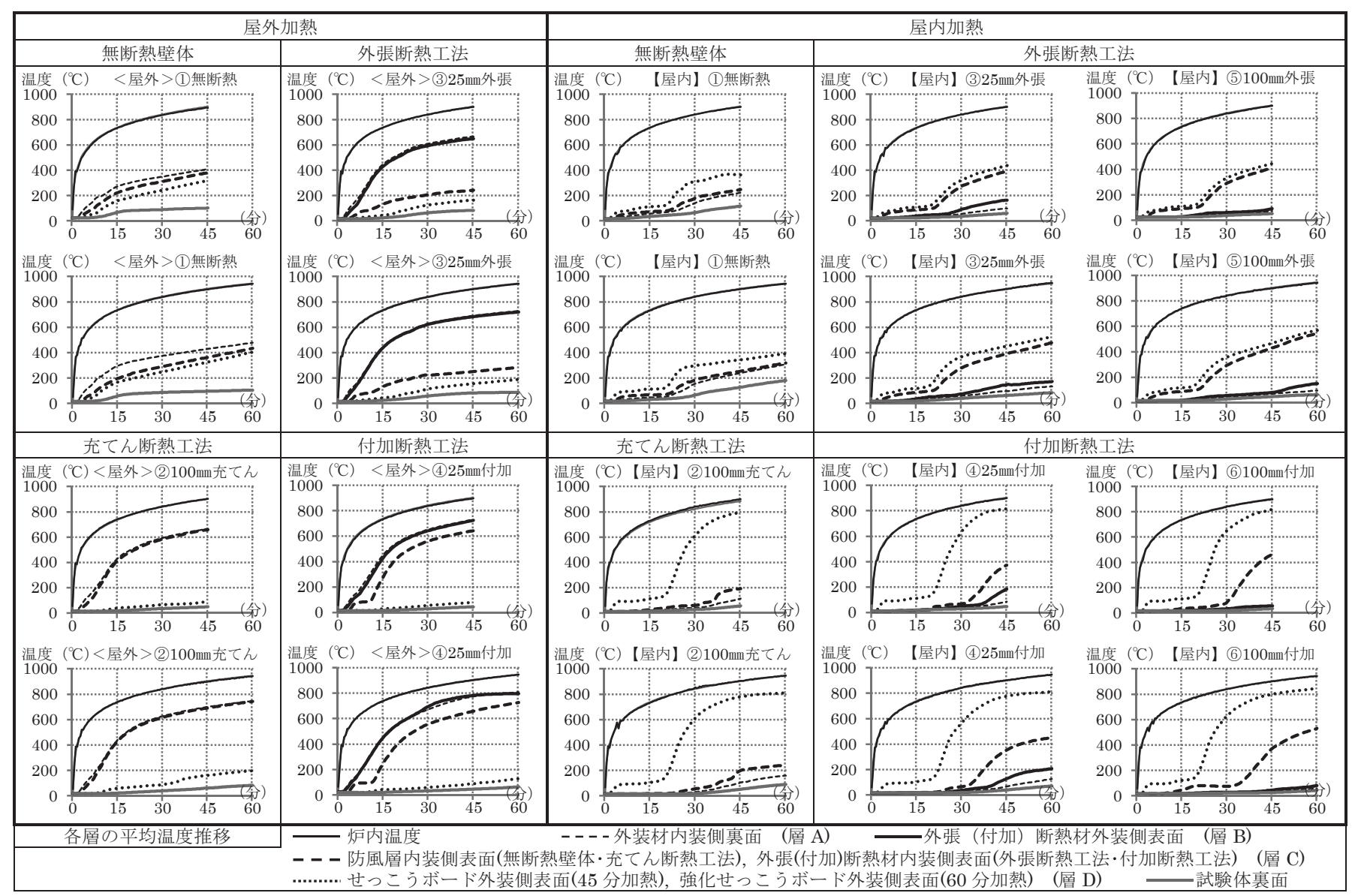

図 3 小型試験体による加熱実験 各層・柱側面の平均温度推移（上段：45 分加熱・下段：60 分加熱） 


\section{(2) 一次元定常熱伝導計算による壁体各層の加熱終了時温度の算出}

ロックウール断熱材は高温でも溶融・燃焼しないため、裏面を含 む試験体内部の温度分布は、熱貫流に支配されると考えられる。特 に防火性能評価の対象となる 45 分、60 分後では一般に裏面温度等 の变化は緩慢であり、試験体内の断面方向の温度分布は両側の気温 を境界条件とする定常熱伝導が成り立つ状態に近づいていると考え られる。そこで定常熱伝導を仮定して内部温度を計算すれば、やや 高温側、即ち危険側で予測できる可能性があると考えて、加熱側 (炉 内温度）の境界条件を加熱終了時における ISO834 加熱曲線が示す 温度 $\left(45\right.$ 分 $902^{\circ} \mathrm{C} 、 60$ 分 $945^{\circ} \mathrm{C}$ )、非加熱側（雰囲気温度）の境界 条件を $20^{\circ} \mathrm{C}$ とて、一次元定常熱伝導計算 (以下、一次元定常計算) を行った。用いた計算モデルと設定条件を表 1 に示す。

なお、各層の熱伝達率、各構成材料の熱伝達率は温度に依存する
ため、本計算では、各部分の温度がこれら物性值に対応する温度と 一致するまで反復計算を行った。実験の過程では水分の蒸発や結晶 水の放出が見られるが、計算では高温部の水分が散逸した後の定常 状態を想定している。そのため、計算では、水分の移動による影響 は高温での材料の物性值以外は考慮していない。また部材の脱落や 損傷も考慮していない。

\section{（3）内部温度の一次元定常熱伝導計算との比較}

45 分加熱および 60 分加熱における加熱終了時の各層の温度分布 を、一次元定常計算値と比較して図 4 に示寸。

全体に計算の方が温度は高く、中空層がない充てん断熱工法及び 付加断熱工法において、実験結果で 60 分加熱の方が 45 分加熱より 計算結果に近いのは、計算が定常加熱を想定しているためと考えら れる。遮熱性や柱に接する内外装・断熱層等、非損傷性に影響する

表 1 一次元定常熱伝導計算における計算モデルと設定条件

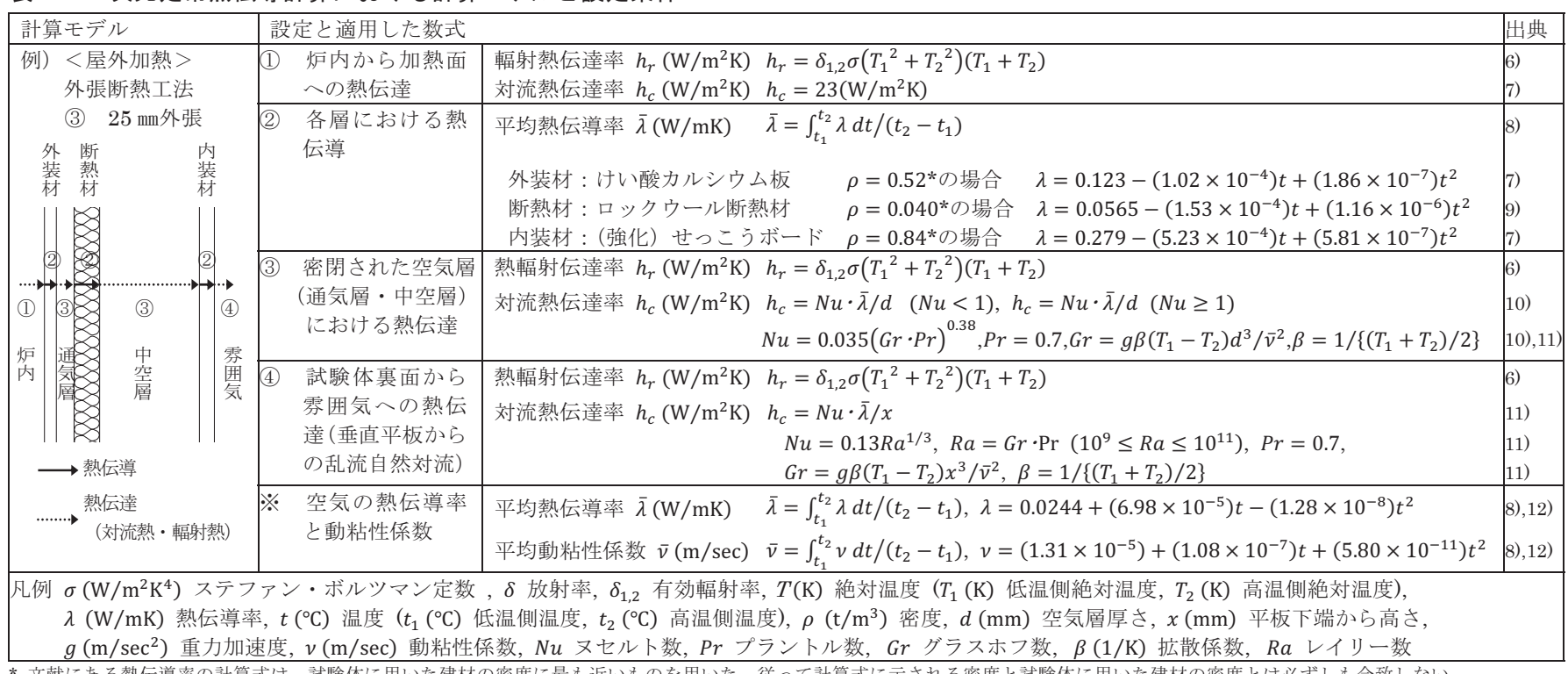

文献にある熱伝導率の計算式は、試験体に用いた建材の密度に最も近いものを用いた。従って計算式に示される密度と試験体に用いた建材の密度とは必ずしも合致しない。



図 4 壁体内各層の温度 （加熱実験の結果と一次元定常計算値） 
材料の加熱終了時の壁体内部温度は、定常計算でやや危険側で比較 的容易に予測できることが分かる。しかし中空層がある無断熱壁体 及び外張断熱工法では、計算值は実験結果に比べて中空層の温度が 著しく高くなって、安全側の設計を導く結果とはなっても、計算値 は実験結果から乘離した注6)。その原因として、中空層境界の熱収支 計算で想定している静止空気層と固体表面間の対流熱伝達の仮定が 加熱実験では成立せず、中空層の熱伝達を過小評価している可能性 があること、計算では系外となる柱の熱容量は中空層よりも大きく、 実験では柱の存在により中空層の温度上昇が抑制されると推測され るが、計算ではその点を評価できていないこと等が考えられる。

\section{4. 遮熱性に関する考察}

\section{(1) 試験体の遮熱性の評価概要}

実験結果に基づく遮炎性・遮熱性の検討結果を表 2 に示す。無断 熱壁体では遮炎性は満たしたが、遮熱性は屋外加熱よりも屋内加熱 で低下し、60 分屋内加熱では所定の性能を満たさなかった。ロック ウール断熱壁体では、すべての試験体で遮炎性、遮熱性を満たした。

\section{（2）遮熱性と熱貫流抵抗との関係性}

試験体断熱部の常温時の熱貫流抵抗と裏面温度上昇度の関係を、 先述の一次元定常計算での結果とあわせて図 5 に示寸。常温時の熱 貫流抵抗が大きくなるほど、裏面温度は低くなる傾向があり、ロッ クウール断熱壁体の遮熱性の序列は、常温時の熱貫流抵抗を比較す
ることにより、概ね予想できることが分かる。

裏面温度はどの条件でも計算值の方が実験值より高くなった。そ の主な原因として、実験では試験終了時点で、最も非加熱側の試験 体裏面では想定する定常状態に達していない可能差が高いことや温 度が高くなるほど、断熱材の熱抵抗が小さくなるため、裏面温度が 高く算出されて実験值との差がより広がった可能性があることなど が考えられる。また中空層のある仕様では、先述のように、実験で は計算より大きい熱損失が生じていることが、さらに影響を大きく している可能性がある。

次に遮熱性を満たす目安となる熱貫流抵抗值を考える。一次元定 常計算で裏面温度上昇度 $140^{\circ} \mathrm{C}$ を超えない熱貫流抵抗の範囲を求め ると、 45 分準耐火外壁で $1.70 \mathrm{~m}^{2} \mathrm{~K} / \mathrm{W}$ 以上、 60 分準耐火外壁で 2.10 $\mathrm{m}^{2} \mathrm{~K} / \mathrm{W}$ 以上となる。この範囲でロックウール断熱壁体を設計する と、裏面温度が実験より高めに推定されるため、図 5 のように、十 分、安全側の設計を誘導することがわかる。

\section{（3）屋外加熱と屋内加熱との比較}

定常熱貫流計算が近似的に成り立てば、加熱を受ける壁体の裏面 温度は雰囲気温度に対し表面熱伝達の分だけ高くなる。そのため同 じ壁体構成であれば、加熱方向に依らず試験体の裏面温度はほぼ同 程度の温度となり、遮熱性にさほど大きな差は生じないはずである。

しかし実験結果を見ると、試験体裏面温度の経過は、壁体構成が 同じでも加熱方向により異なり（図 6 )、無断熱壁体、充てん断熱工

\section{表 2 遮炎性・遮熱性の検討結果}

\begin{tabular}{|c|c|c|c|c|c|c|c|c|c|c|c|c|c|}
\hline \multirow{5}{*}{\begin{tabular}{|l} 
加熱 \\
時間
\end{tabular}} & \multirow{5}{*}{$\begin{array}{l}\text { 防火 } \\
\text { 性能 }\end{array}$} & \multirow{2}{*}{\multicolumn{2}{|c|}{$\begin{array}{l}\text { 加熱方向 } \\
\text { 断熱工法 }\end{array}$}} & \multicolumn{4}{|c|}{ 屋外加熱 } & \multicolumn{6}{|c|}{ 屋内加熱 } \\
\hline & & & & \multirow{2}{*}{$\begin{array}{l}\text { 無断熱壁体 } \\
\text { (1) 無断熱 }\end{array}$} & \multirow{2}{*}{\begin{tabular}{|l|l|} 
充てん断熱工法 \\
(2) 100 血充てh \\
\end{tabular}} & \multirow{2}{*}{\begin{tabular}{|l|} 
外張断熱工法 \\
(3) $25 \mathrm{~mm}$ 外張 \\
\end{tabular}} & \multirow{2}{*}{\begin{tabular}{|l} 
付加断熱工法 \\
(4) $25 \mathrm{~mm}$ 付加 \\
\end{tabular}} & \multirow{2}{*}{\begin{tabular}{|l|} 
無断熱壁体 \\
(1) 無断熱 \\
\end{tabular}} & \multirow{2}{*}{\begin{tabular}{|l|} 
充てん断熱工法 \\
(2) 100 西充てh \\
\end{tabular}} & \multicolumn{2}{|c|}{ 外張断熱工法 } & \multicolumn{2}{|c|}{ 付加断熱工法 } \\
\hline & & 試 & 体仕様 & & & & & & & (3) $25 \mathrm{~mm}$ 外張 & (5) $100 \mathrm{~mm}$ 外張 & (4) $25 \mathrm{~mm}$ 付加 & (6) $100 \mathrm{~mm}$ 付加 \\
\hline & & 熱貫流抵抗"1 & 45 分準耐火仕様 & 0.38 & 3.01 & 1.12 & 3.66 & 0.38 & 3.01 & 1.12 & 3.10 & 3.66 & 5.64 \\
\hline & & $\left(\mathrm{m}^{2} \mathrm{~K} / \mathrm{W}\right)$ & 60 分準耐火仕様 & 0.37 & 3.00 & 1.12 & 3.66 & 0.37 & 3.00 & 1.12 & 3.09 & 3.66 & 5.63 \\
\hline \multirow{3}{*}{$\begin{array}{l}45 \text { 分 } \\
\text { 加熱 }\end{array}$} & 遮炎性 & \multicolumn{2}{|c|}{$\begin{array}{c}\text { 炎の貫通の有無 } \\
\end{array}$} & なし & なし & なし & なし & なし & なし & なし & なし & なし & なし \\
\hline & \multirow[t]{2}{*}{ 遮熱性 } & \multicolumn{2}{|c|}{ 試験体裏面の初期温度 $\left({ }^{\circ} \mathrm{C}\right)$} & 23 & 16 & 16 & 16 & 17 & 13 & 22 & 25 & 14 & 16 \\
\hline & & \multicolumn{2}{|c|}{ 裏面温度上昇度 $(\mathrm{K})$ 平均 /最高 } & $78 / 80$ & $37 / 39$ & $67 / 69$ & $29 / 32$ & $100 / 114$ & $45 / 59$ & $37 / 42$ & $27 / 30$ & $35 / 38$ & $18 / 21$ \\
\hline \multirow{3}{*}{$\begin{array}{l}60 \text { 分 } \\
\text { 加熱 }\end{array}$} & 遮炎性 & \multicolumn{2}{|c|}{ 炎の貫通の有無 } & なし & なし & なし & なし & なし & なし & なし & なし & なし & なし \\
\hline & 遮熱性 & \multicolumn{2}{|c|}{ 試験体裏面の初期温度 $\left({ }^{\circ} \mathrm{C}\right)$} & 16 & 18 & 18 & 19 & 19 & 17 & 17 & 17 & 17 & 17 \\
\hline & & \multicolumn{2}{|c|}{ 裏面温度上昇度 $(\mathrm{K})$ 平均 /最高 } & $89 / 98$ & $64 / 67$ & $72 / 73$ & $45 / 51$ & $162^{* 1} / 179$ & $73 / 84$ & $67 / 79$ & $47 / 48$ & $55 / 57$ & $25 / 31$ \\
\hline
\end{tabular}

*1 試験を㥶施した小型試験体で、柱や枠材の熱橋を考慮せず、断熱材部のみを対象に、中空層や通気層は上端と下端を塞いだ空気層と見なし、外装材から内装材の層構成で算出した。 *2 加熱開始 53.5 分時の測定にて、遮熱性の規定值（裹面温度上昇度の平均值 $140 \mathrm{~K} ）$ を超えて、遮熱性を満足しなくなった。

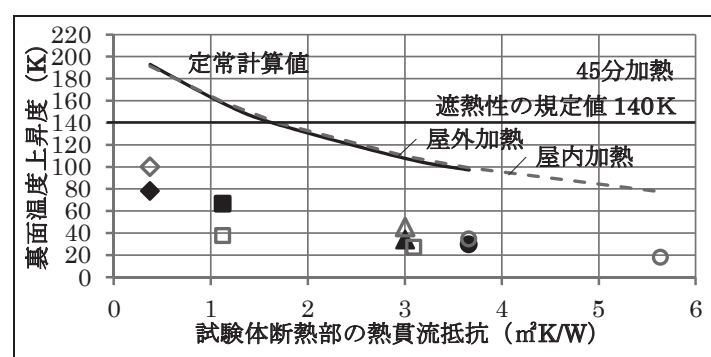

図 5 試験体断熱部の熱貫流抵抗と裏面温度上昇度 (平均)

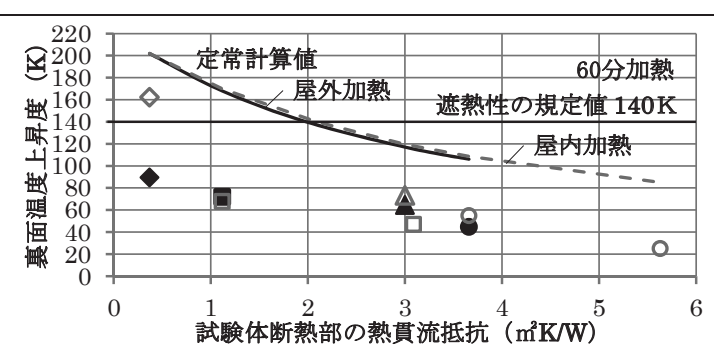

（左：45 分加熱·右 : 60 分加熱）

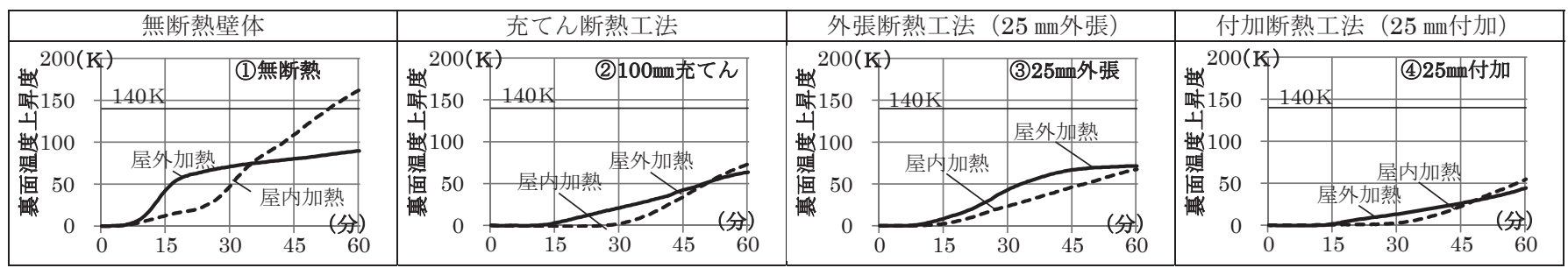

図 6 断熱工法別・加熱方向による裏面温度上昇度（平均）の比較 
法、付加断熱工法（25 mm付加断熱壁体）では屋内加熱の方が高く、 外張断熱工法 $(25 \mathrm{~mm}$ 外張断熱壁体) では屋外加熱の方が高くなった。

屋内加熱では、加熱開始後、炉に暴露されるせっこうボードの結 晶水が $100^{\circ} \mathrm{C}$ 付近で放出される間はその非加熱側の温度上昇は低く 抑えられ、温度停滞が終わった後は急激に上昇した。一方、屋外加 熱では、試験体の裏面温度は時間の経過とともに単調に上昇し、裏 面温度上昇度が約 $60^{\circ} \mathrm{C}$ を超えると傾きが小さくなってほぼ横ばい に推移した。最も非加熱側に位置するせっこうボードの加熱側表面 がようやく $100^{\circ} \mathrm{C} に$ 達した時に、温度停滞が生じたとみられる。

火災加熱時の壁体の遮熱性に見られるこの非対称性は、壁体の屋 外・屋内方向に非対称に配置された材料の熱的特性の温度依存性や 高温での吸発熱の有無が各々異なることに起因すると考えられる。 例えば、せっこう系面材を含む壁体は結晶水を放出する間は、熱貫 流が抑制されるが、さらに高温となると熱伝導率が上昇し、熱貫流 を援けるため、加熱時の温度と加熱時間によって、遮熱性に関して は有利にも不利にも働く。外張断熱工法以外、屋内加熱時の方が、 遮熱性が低下したのは、屋内側表面のせっこうボード又は強化せっ こうボードの結晶水の放出が早く始まり、熱伝導率が上昇した状態 が長く続いたためと考えられる。そして、外張断熱工法のみ屋外加 熱時の方が屋内加熱より遮熱性が低くなったのは、屋内加熱時に早
く高温に達する中空層において、前述のように顕著な熱損失があっ たためと考えられる。無断熱壁体も中空層を有するが、断熱層がな いため、その温度は加熱方向とほとんど無関係である。

\section{（4）中空層が遮熱性に及ぼす影響}

本実験から、断熱外壁に中空層が設けられると遮熱性に大きな影 響が生じることが分かった。中空層は、火災加熱時に温度上昇が著 しい部分に配置した場合に遮熱性の向上に大きな効果がある結果と なったが、その影響は、中空層内で激しい対流が生じているか、中 空層に露出する柱等の木造部材による吸熱・温度上昇抑制に起因す る可能性がある。前者については更に中空層の厚さ・高さが影響す る可能性があり、後者については柱・間柱等の断面が中空層に占め る割合は工法によって異なり、また本実験のような小型試験体と実 大壁体でも異なる。そのため中空層がある壁体の火災加熱時の内部 温度・遮熱性の実用的な予測については、小型試験体での再現性に 限界がある可能性の検討も含め、今後、中空層内の熱伝達の状況や 柱の熱容量による影響など、中空層内の熱収支を把握し、それに基 づくモデル化の考察が必要と考える。

\section{5. 柱の損傷度（非損傷性）に関する考察}

(1) 加熱側柱角部の炭化と柱の損傷度との関係

表 3 柱最小断面の断面積残存率と断面二次モーメント

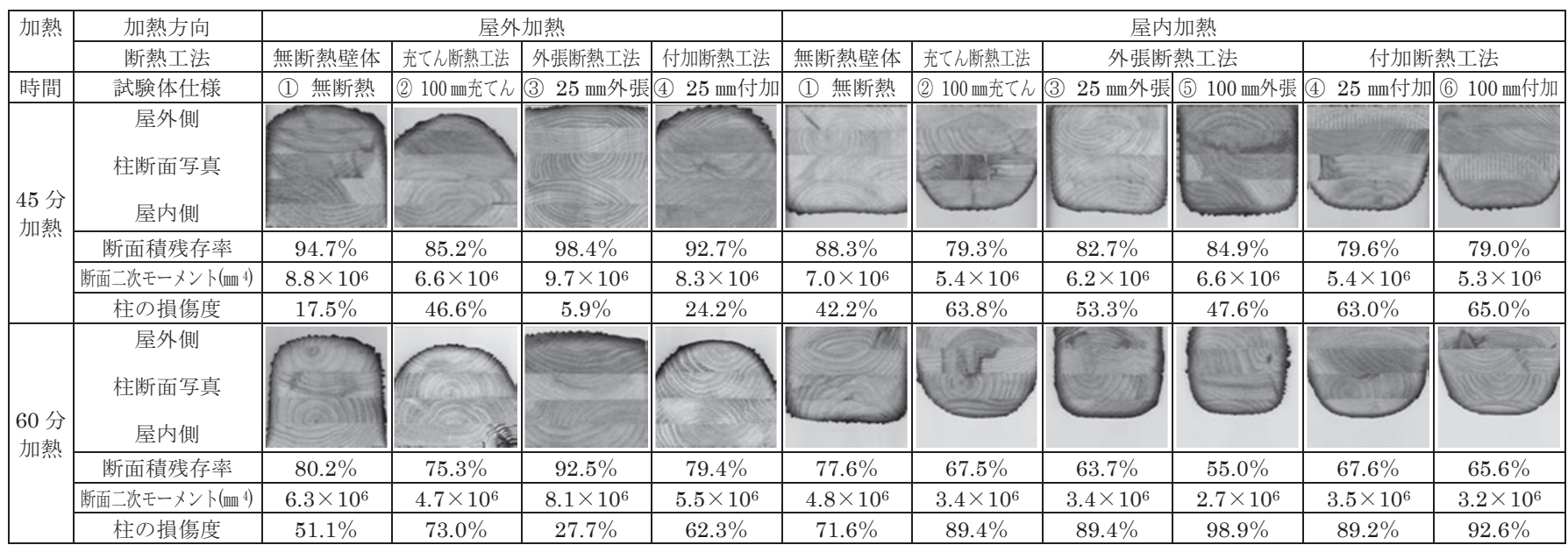

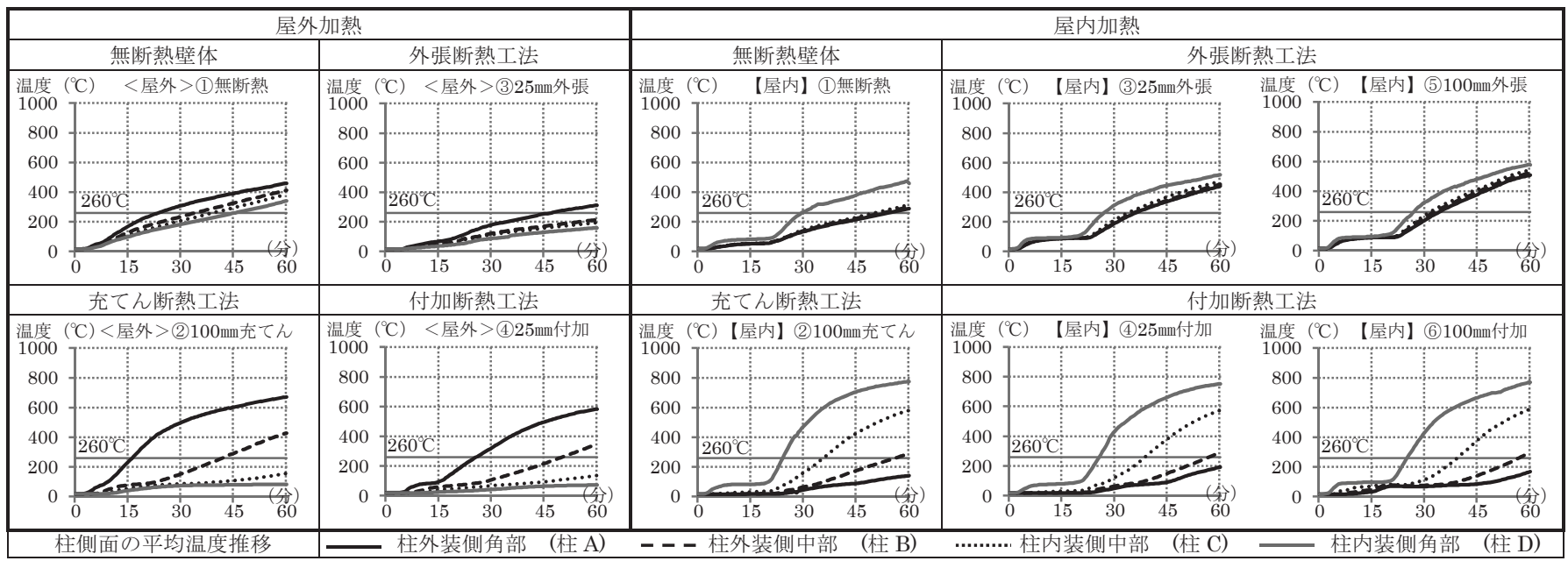

図 760 分加熱時の柱側面の平均温度推移 
柱最小断面の断面積残存率と断面二次モーメントを表 3 に、60 分 加熱時の柱側面の平均温度推移を図 7 に示寸。炭化による柱の断面 減少には多様なパターンが認められる (表 3 ) が、加熱側柱角部の 炭化深さと断面二次モーメントの減少分との間に強い相関性が確認 された（図 8)。そこで断熱工法における柱の断面二次モーメントの 低下の状況は、柱の加熱側柱角部での炭化の進行によって把握でき ると考え、以下、加熱側柱角部に着目し考察を進めていく。

\section{(2) 柱の燃焼が始まる時間}

加熱側柱角部の温度上昇は、加熱面から柱の加熱側表面までの被 覆（以下、被覆層）を厚くして熱抵抗を大きくし、かつ被覆層より 非加熱側に位置する軸間および柱を含む被覆層以外の熱抵抗を小さ くして、加熱側への放熱が促されるほど抑制されるはずである。

柱の燃焼開始時間を加熱側柱角部の温度が $260^{\circ} \mathrm{C}$ を超える時間と 定義し、内装材および中空層（充てん断熱層）の仕様はほぼ共通す るため、柱の燃焼開始時間と外装材や外張断熱層等の外装被覆の熱 抵抗の関係注 7)（図 9）を検討寸る。

屋外加熱では、柱の燃焼開始時間は、外装被覆の熱抵抗が高くな ると遅くなり、充てん断熱材により非加熱面側への放熱が抑制され ると早まる傾向が顕著に現れた。特に充てん断熱工法が、断熱工法 の中で柱の燃焼開始時間が最も早い。屋内加熱では、加熱側柱角部 の温度はいずれもせっこうボードの結晶水の放出による $100^{\circ} \mathrm{C}$ 付近 での温度停滞が終わった後、急激に上昇して $260^{\circ} \mathrm{C}$ 超える (図 7 )。 柱の燃焼開始時間は、せっこうボードによる $100^{\circ} \mathrm{C}$ 付近での温度停 滞時間の影響が支配的であり、充てん断熱材があると 1 分〜 3 分程 度早まるが断熱工法による影響は小さい。

（3）屋外加熱と屋内加熱との比較

外壁の場合、外装被覆には構造用面材や外装材など、断熱材以外 にも面材が複数設置されることが多い。それに対し内装被覆はせっ こうボードだけである場合が多く、外装被覆に比心゙被覆が薄い傾向 がある。従って、外壁の非損傷性は、屋内加熱の方が屋外加熱に比 ぶ不利になる傾向が強いと予想される。
実験結果を見ると、予想通り、無断熱壁体およびすべての断熱仕 様で 45 分加熱、60 分加熱ともに、屋内加熱の方が屋外加熱より断 面二次モーメントが小さくなった（表 3 )。柱の損傷度は屋内加熱の 方が屋外加熱よりも不利となり、断熱化してもこの傾向は変わらな いことが分かる。この加熱方向による柱の損傷度の差は、無断熱壁 体で約 20〜25\%程度、充てん断熱工法で約 25～27\%程度となり、 外張断熱工法、付加断熱工法では、外張（付加）断熱材によりさら

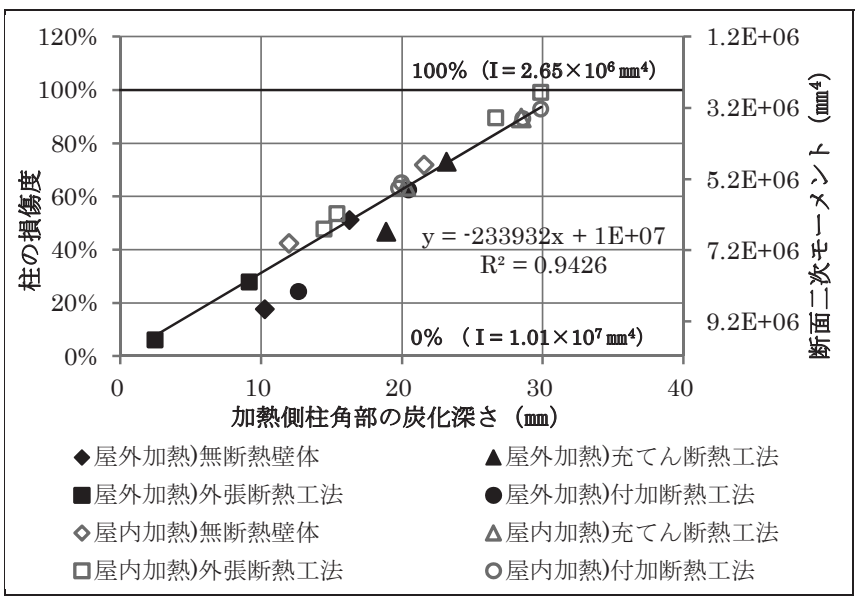

図 8 加熱側柱角部の炭化深さと柱の損傷度（最小断面）

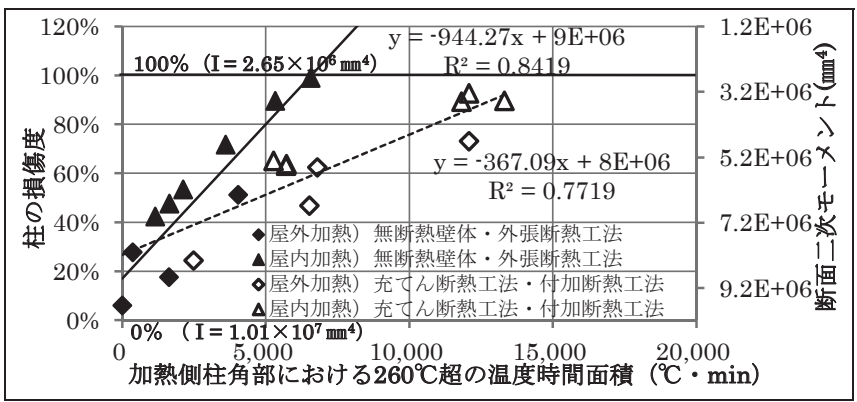

図 $10260^{\circ} \mathrm{C}$ 超の温度時間面積と柱の損傷度（加熱側柱角部）
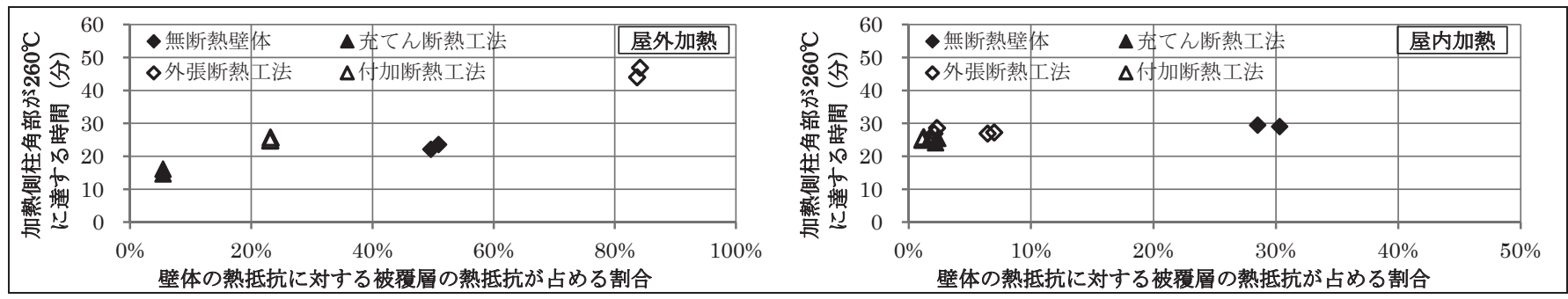

図 9 外装被覆の熱抵抗と加熱側柱角部が $260^{\circ} \mathrm{C} に$ 達する時間（左：屋外加熱・右：屋内加熱）
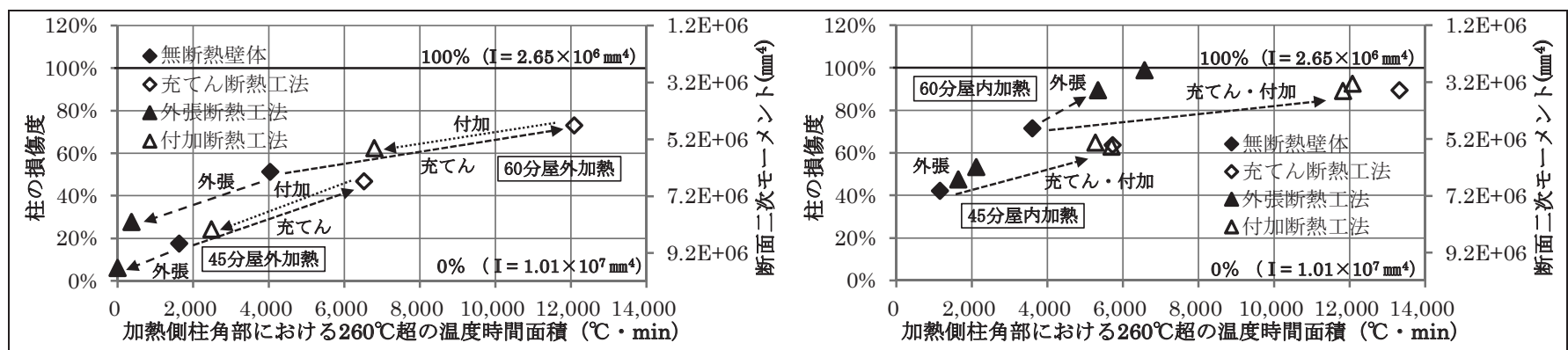

図 11 断熱工法ごとの $260^{\circ} \mathrm{C}$ 超の温度時間面積と柱の損傷度（左：屋外加熱・右：屋内加熱） 
に広がった（表 3 ）。特に無断熱壁体と充てん断熱工法では、屋外加 熱時、柱の屋外側正面に留め付けられた通気胴縁が柱を被覆する役 割を果たした可能性が考えられ、その結果、加熱側柱正面および柱 角部の断面欠損を軽減、抑制したことが、屋内加熱時に比べ柱の損 傷度に 2 割を超寸差が生じた一因と考えられる。

なお、ロックウール断熱壁体の寸べての断熱仕様で 60 分屋内加 熱時の柱の損傷度は 100\%を超えないが、約 $90 \%$ 前後またはそれ以 上までに達し、部材内の温度上昇によるヤング率の低下を考慮して いない範囲ですでに、非損傷性の限界に対し余裕が少なくなってい ることについては留意が必要である。

\section{(4) 断熱工法と柱の損傷度}

加熱側柱角部における $260^{\circ} \mathrm{C}$ を超えた部分の温度時間面積（受熱 量）と柱の損傷度との関係を見ると、充てん断熱材がある場合とな い場合に分かれ、それぞれ相関性が認められた（図 10）。充てん断 熱材の有無により柱が受ける受熱量と柱の損傷度の関係が変化する。 断熱工法ごとに見る（図 11）と、屋外加熱では充てん断熱工法が、 45 分屋内加熱では充てん断熱工法と付加断熱工法が、60 分屋内加 熱では外張断熱工法が、それぞれ柱の損傷が最も進んでいる。特に 屋内加熱では、すべての断熱工法で無断熱壁体よりも柱の受熱量が 増えて損傷が進んでおり、断熱化が柱の損傷を促進させる傾向があ るといえる。

\section{(1) 充てん断熱工法と無断熱壁体との比較}

充てん断熱工法では無断熱壁体に比べ、屋外加熱、屋内加熱とも に柱の断面二次モーメントは小さくなり、柱の損傷度は約 18～ $29 \%$ 大きくなった（図 11）。充てん断熱材により加熱側被覆層裏面で温 度が高くなり (図 3 )、加熱側柱正面および柱角部の損傷が進んだが、 柱側面では加熱面から離れるにつれて温度が低くなり（図 7 )、柱の 損傷も抑制された（表 3 )。これにより、充てん断熱によって非損傷 性が不利になる要因と有利に働く要因の両方があることが分かるが、 本実験の範囲では、全体としては断熱が柱の損傷に対し不利側に働 いている。

\section{(2) 外張断熱工法と無断熱壁体との比較}

外張断熱工法では無断熱壁体に比べ、柱の断面二次モーメントは 屋外加熱では大きく、屋内加熱では小さい（表 3、図 11）。屋外加 熱では、柱の炭化は屋外側正面にほぼ限られるのに対して、屋内加 熱では柱側面の炭化が無断熱壁体や他の断熱工法よりも大きく、60 分加熱では特に顕著である (表 3 )。外張断熱工法では、屋外加熱で は被覆材として中空層温度を低く保ったまま柱の損傷を抑えたが、 屋内加熱では柱・中空層から非加熱側への放熱を妨げるため、柱の 側面を含めて柱の受熱量を増やし、損傷を促進させることが分かる (表 3 、図 7 )。屋内加熱時の外張断熱材厚さが非損傷性に及ぼす影 響が 45 分以降に顕在化し、60 分加熱で顕著になるのは、加熱側被 覆のせっこうボードの結晶水の放出後、中空層温度が不連続的に上 昇し始めるのが約 20 分 (図 3、図 7 ) であり、時間の経過ととも に柱への入熱が大きくなるためと考えられる。

\section{(3) 付加断熱工法と充てん断熱工法との比較}

付加断熱工法では、付加断熱層が屋外加熱に対して充てん断熱 層・柱の被覆となり柱の損傷を抑えるが、屋内加熱時は、付加断熱 層の加熱側境界温度が上昇すると充てん断熱層・柱からの熱損失を 抑制し、その温度を上昇させると考えられる。本実験では、付加断
熱工法は充てん断熱工法と比べ、柱の断面二次モーメントは、それ から予想されるように屋外加熱では大きくなったが、屋内加熱では 付加断熱材の有無、厚さに依らず同程度となった（表 3 、図 11）。 屋内加熱時の柱側面温度（図 7 ）は、付加断熱材の有無、厚さに関 係なく、ほぼ一致しており、ロックウール断熱材 $100 \mathrm{~mm}$ の充てん断 熱層に対しては 45〜60 分では、非加熱側の付加断熱層の断熱性能 は充てん断熱層・柱の温度に特に影響を与えないことを示している。

\section{(4) 付加断熱工法と外張断熱工法との比較}

外張断熱工法では、中空層が屋外加熱時には低温に保ち、屋内加 熱時には急激に温度上昇した（図 3 、図 7 ) が、付加断熱工法では、 この中空層の効果は消失するから、付加断熱工法は、屋外加熱に対 しては外張断熱工法より柱の損傷が不利になる。屋内加熱に対して は柱側面の損傷は有利になるが、加熱側被覆層の裏面温度は、充て ん断熱により上昇するため、不利になるという二面性が予想される。

本実験で試験を実施した外張（付加）断熱材厚さ $25 \mathrm{~mm}$ では、屋 外加熱に対し、付加断熱工法の方が外張断熱工法よりも、柱の断面 二次モーメントは小さくなった（表 3 ）。一方、前報 1)では、屋外加 熱に対する付加断熱工法と外張断熱工法における柱の断面欠損の差 は、外張（付加）断熱材が厚くなるにつれ小さくなる傾向があり、 厚さ $100 \mathrm{~mm}$ になると差はほとんどみられなかった。従って、屋外加 熱時の柱の損傷に予想される付加断熱工法の外張断熱工法に対する 不利は、外張（付加）断熱材と充てん断熱材の厚さの相対的な関係 で決まり、外張（付加）断熱材が充て几断熱材と同等となれば、充 てん断熱材の影響はほぼ解消寸ると考えられる。

屋内加熱時の柱の断面二次モーメントは、45 分加熱では付加断熱 工法の方が小さくなったが、60 分加熱では、外張断熱工法の方が小 さいかほぼ同程度となった (表 3 )。外張断熱工法で柱側面の損傷が 進まないうちは、付加断熱工法で充てん断熱材により加熱側被覆層 裏面で温度が高くなり（図３）、不利になる方が卓越する。一方、付 加断熱工法で充てん断熱材が柱の損傷を抑えて有利に働く効果は、 外張断熱工法にて柱への入熱が大きくなり柱側面の損傷が進む段階 になってようやく顕在化することが分かる（表 3 、図 7 )。

\section{(5) 柱の損傷度の予測可能性}

これまで加熱側柱角部に着目して柱の損傷度（非損傷性）につい て考察してきたが、柱の温度は試験による実測以外に把握が難しい。 加熱側の被覆層裏面の温度から柱の損傷度との関係性を明らかにで きれば、一次元定常計算により加熱側の被覆層裏面の温度を求める ことで、柱の損傷度についてある程度の予想が可能になると考えら れる。

そこで被覆層裏面における $260^{\circ} \mathrm{C}$ を超えた部分の温度時間面積と 柱の損傷度との関係（図 12）を見ると、加熱側柱角部と柱の損傷度 との関係（図 10）とほぼ同じ傾向がある。加熱終了時の被覆層裏面 温度は、 $260^{\circ} \mathrm{C}$ を超えた部分の温度時間面積（受熱量）が大きくな るほど高くなる傾向（図 13）があり、柱の損傷度と加熱終了時の被 覆層裏面温度の関係は、充てん断熱材の有無により異なる傾向を示 すことがわかる（図 14）。よって、充てん断熱材の有無に応じて、 加熱終了時の被覆層裏面温度から、柱の損傷度（非損傷性）を予測 できる見通しが得られたといえる。加熱終了時の被覆層裏面温度は、 充てん断熱材があり中空層がない場合は、一次元定常計算によりや や高温側で予想できる見通しが得られたので、柱の損傷度（非損傷 
性）も同様に予想できる可能性がある（図 15）。なお、充てん断熱 材がなく中空層がある仕様では、前述のように中空層の熱収支に試 験体が小型であることの影響が現れた可能性があり、柱の損傷度に ついても、その影響が生じている可能性を検討する必要があろう。

なお、木柱の非損傷性には、先述のように断面減少だけでなくヤ ング係数の温度依存性も影響するが、充てん断熱材の有無等は柱側 面の内部温度への影響を通じて、ヤング係数の差異を引き起こすと 考えられる。断熱工法により、柱内部の温度分布にどのような差が 生じうるかについては、本実験で得られた柱の加熱性状に関する知 見をもとに、柱内部温度測定に関寸る既往研究 ${ }^{4)}$,14)に示されている 手法等を参照して、今後の課題としたい。

\section{6. まとめ}

本研究では、断熱材や断熱工法が外壁の防火性能に及ぼす基本的 な影響を、火㷋加熱中に断熱材が溶融・燃焼しない最も基本的な条 件で把握するため、ロックウール断熱材を用いた 45 分、60 分準耐 火軸組木造外壁を対象に、小型試験体による非載荷の加熱実験を実 施し、考察を行った。ロックウール断熱材のように、火災加熱下で の燃焼・溶融を無視できる断熱材を使用する木造断熱壁体について は、以下のように結論できる。

\section{(1) 壁体内の温度推移と温度分布}

45 分、60 分火災加熱終了時の木造断熱壁体の内部温度分布は、 中空層がない場合は一次元定常計算によりやや高温側で予測できる ことが分かった。一方、中空層がある無断熱壁体、外張断熱工法で は、中空層において計算值と実験結果の温度が乘離した。この原因 として一次元定常計算で想定した中空層境界面での対流熱伝達の仮 定が加熱実験では成立せず、中空層の熱伝達を過小評価している可 能性があること、また一次元定常計算では系外となる柱の熱容量が 影響する可能性があることが考えられる。中空層の熱収支の把握と
計算モデルの構築は今後の課題である。

(2) 遮熱性

ロックウール断熱材による木造断熱壁体の遮熱性について、一次 定常計算では、試験体裏面温度は実験值に比べ高温側で算出される が、遮熱性の序列は評価する加熱時間ごとに常温時の熱貫流抵抗を 比較することで予想できる。壁体断熱部における常温時の熱貫流抵 抗が 45 分準耐火外壁で $1.70 \mathrm{~m}^{2} \mathrm{~K} / \mathrm{W}$ 以上、 60 分準耐火外壁で 2.10 $\mathrm{m}^{2} \mathrm{~K} / \mathrm{W}$ 以上あれば、遮熱性は十分確保される見通しが得られた。

遮熱性は、高温で相変化を伴う材料や中空層の配置により、屋外 加熱と屋内加熱に差異が生じ、屋内側内装をせっこうボードとする 場合、無断熱壁体および充てん断熱工法、付加断熱工法では屋内加 熱の方が不利になることが分かった。また遮熱性は中空層があると 有利になる結果となったが、中空層の熱収支の要素となる中空層両 側表面の間の対流熱伝達及び中空層・柱間の熱交換については寸法 の影響が現れる可能性があり、小型試験体による防火性能の検討の 有効性に関しては、今後、中空層内の熱伝達の状況や柱の熱容量に よる影響を把握するなど、工学的な検討が必要である。

(3) 柱の損傷度（非損傷性）

屋内側内装をせっこうボードとする場合、柱の燃焼が始まる時間 は屋外加熱では外装被覆の熱抵抗、屋内加熱ではせっこうボード非 加熱側表面の $100^{\circ} \mathrm{C}$ 付近での温度停滞時間に依存する。また無断熱 壁体およびロックウール断熱壁体のすべての断熱工法で、柱の損傷 は、屋内加熱の方が屋外加熱より進んで不利になる傾向がある。

充てん断熱材は、本研究の範囲では柱の損傷に不利側に働いたが、 柱断面形状一の影響を見ると、加熱側被覆層裏面温度を上昇させて 不利に働く面と柱側面の損傷を抑制して有利に働く面の二面性があ る。一方、外張（付加）断熱材が柱の損傷に及ぼす影響は、屋外加 熱では柱の被覆材となり有利に働き、屋内加熱では非加熱側への放 熱を妨げて不利に働いている。断熱工法ごとの非損傷性の特徽は、

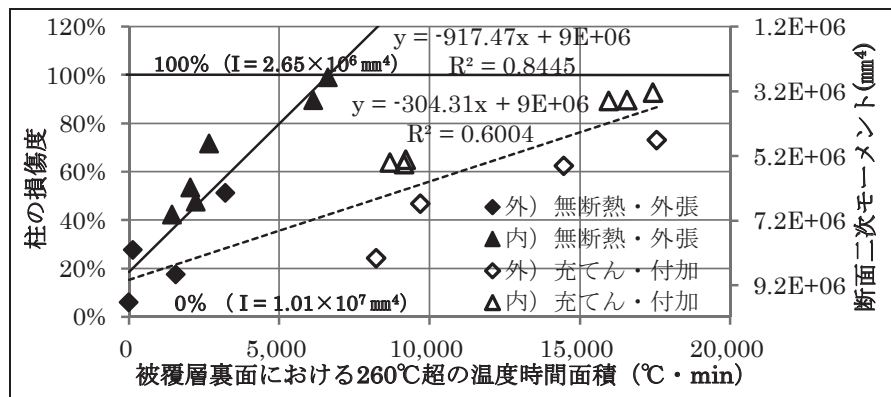

図 $12260^{\circ} \mathrm{C}$ 超の温度時間面積と柱の損傷度（被覆層裏面）

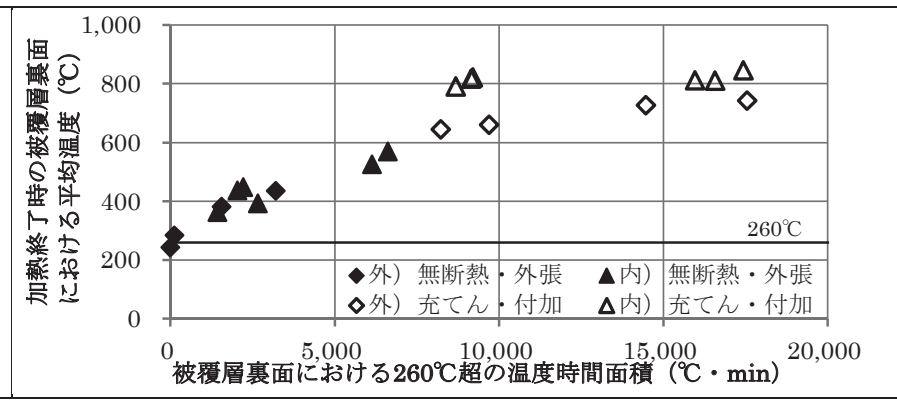

図 $13260^{\circ} \mathrm{C}$ 超の温度時間面積と加熱終了時の温度（被覆層裏面）

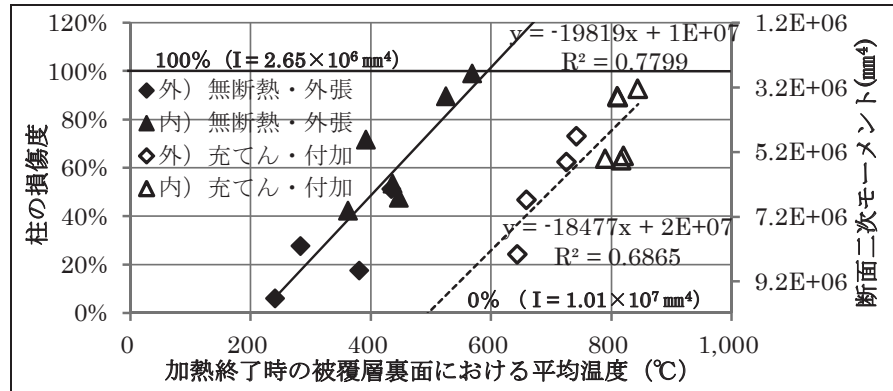

図 14 加熱終了時の被覆層裏面温度と柱の損傷度

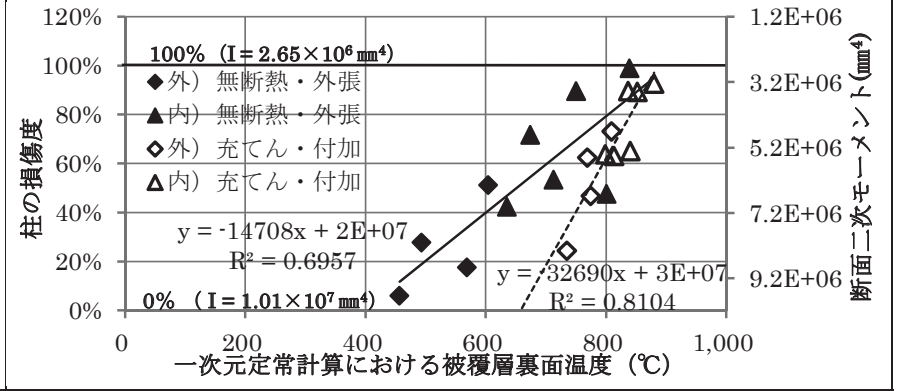

図 15 一次元定常計算における被覆層裏面温度と柱の損傷度

※図 12〜図 15 中にある外）は「屋外加熱」、内）は「屋内加熱」、無断熱・外張は「無断熱壁体・外張断熱工法」、充てん・付加は「充てん断熱工法・付加断熱工法」であることを示す。 
この充てん断熱材と外張（付加）断熱材の働きの組み合わせから説 明できる。ただし充てん断熱材の有無による非損傷性の優劣は、柱 の損傷度だけでは判別できず、柱内部の温度推移に基づく力学的物 性の変化も考慮して検討する必要がある。

さらに加熱時の柱の加熱側被覆層裏面温度から柱の損傷度を予想 できる見通しが得られた。特に充てん断熱材があり中空層がない場 合の壁体内温度分布は、一次元定常計算でやや危険側で予測できる ので、非損傷性についても、壁体内の温度分布をさらに精度よく予 測できれば、壁体内部温度の計算から予想できる見通しが得られた と考える。

今後は、充てん断熱材による柱の内部温度および力学的物性の変 化が非損傷性に及ぼす影響の把握や本実験で小型試験体による実験 に限界がある可能性が示唆された課題の検討とともに、高温での溶 融・燃燒等が予想される他種の断熱材についても木造断熱外壁の防 火性能の考え方を整理したい。

\section{謝辞}

本研究は、LIXIL 住生活財団 2012 年度研究助成「熱変性が少な い断熱材を用いた木造壁体の防火設計に関寸る研究」にて実施した 研究成果の一部に、あらためて考察を加えてまとめたものである。 本研究の実施にあたっては、宮崎孝司氏、小竹和広氏、高橋淳一 氏をはじめロックウール工業会の皆様方に多大なるご助言、ご協力 を賜りました。ここに深く感謝の意を表します。

\section{関連する既往発表論文}

*1）系毛治，鈴木大隆，長谷見雄二 : 小型試験体による木造断熱壁体の非損 傷性の検討 その 1 ロックウール断熱材を対象とした検討, 日本建築学会大 会(北海道)学術講演梗概集, 2013.9

*2）系毛治，鈴木大隆，長谷見雄二：小型試験体による木造断熱壁体の非損 傷性の検討 その 4 ロックウール断熱材を対象に加熱時間ごとの検討, 日本 建築学会大会(近畿)学術講演梗概集,2014.9

\section{参考文献}

1）系毛治, 長谷見雄二, 鈴木大隆：ロックウール断熱材を用いた木造断熱壁 体の防耐火性能に関寸る研究, 日本建築学会環境系論文集, 第 676 号, pp433-441, 2012.6

2）財団法人建築環境省エネルギー機構 : 住宅の省エネルギー基準の解説第 3 版第 7 刷, 2010.12

3）地方独立行政法人北海道立総合研究機構 : 防耐火性能試験・評価業務方法 書, 2015.6

4）安井昇, 長谷見雄二, 秋月通孝, 馬屋原敦, 大西卓, 上島基英, 畑俊充, 木 村忠紀, 田村佳英, 村上博: 木造土壁の各部仕様が防耐火性能に及ぼす影響, 日本建築学会環境系論文集, 第 567 号, pp7-13, 2003.5

5) 小幡守著: 最新建築学シリーズ 3 . 最新 建築構造力学 I 第 1 版第 8 刷, 森 北出版侏, 1994.9

6）田中俊六, 武田仁, 土屋喬雄, 岩田利枝, 寺尾道仁 : 最新建築工学 [改訂 3 版了，(侏井上書院, 2009

7) (一社) 日本建築学会 : 鋼構造耐火設計指針, (一社) 日本建築学会, 2008

8）日本工業標準調査会：JIS A 9501 保温保冷工事施工基準, 2014

9) (株)ニチアス : ロックウール MG 製品カタログ, 2015

https://www.nichias.co.jp/products/download/PDF/I02.PDF, (参照日 2015.8.10)

10）日本工業標準調查会: JIS R 3107 板ガラス類の熱抵抗及び建築における 熱貫流率の算定方法, 1998

11) (一社)日本機械学会 : JSMEテキストシリーズ 伝熱工学, (一社)日本機械 学会, 2005

12) (一社) 日本機械学会: 伝熱工学資料 改訂第 3 版, (一社)日本機械学会, 1975
13）社団法人日本建築学会編：構造材料の耐火性ガイドブック，2009.3 14）清水真理子, 長谷見雄二, 村上雅英, 安井昇 : 木造真壁の耐火性能予測, 日本建築学会構造系論文集, 第 611 号, pp165-170, 2007.1

15）小国勝男，菅原進一，高田司：壁体内のプラスチックフォームの燃焼性, 日本建築学会大会学術講演梗概集 A 分冊, pp815-816, 1987.10

16）水上点晴：耐火試験結果を用いたバリエーションの認定に関する研究, BRI-H26 講演会テキスト独立行政法人建築研究所講演会 日本を支える 建築技術 建研の取組み一国立研究開発法人スタートー, 独立行政法人建 築研究所, 2015.3

注

注 1）木造断熱壁体の防火性能について、有機系断熱材を対象にその燃焼性に 着目した検討した報告例 15) はあるが、断熱工法の観点から断熱材の設置位 置や厚さを与条件に壁体の防火性能に及ぼす影響を体系的に考察した報告 は前報 1)以外、見当たらない。なお前報 1)では、ロックウール断熱材を用い た木造壁体を対象に小型試験体による実験により、断熱工法ごとに、加熱 方向に対する断熱材の設置位置、厚さと防火性能との一般的な関係を把握 したが、防火構造を基本に設計された壁体で検討した。本研究では、準耐 火外壁を想定した防火性能の予測可能性を検討寸るため、あらためてロッ クウール断熱材を用いて検討を行った。

注 2） 45 分準耐火構造の場合は、内装材の仕様を平成 12 年建設省告示第 1358

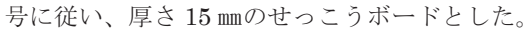

注 3） 60 分準耐火構造の場合は、平成 12 年建設省告示第 1380 号に従うと、 内装材の仕様は厚さ $16 \mathrm{~mm}$ 強化せっこうボードとなるが、市場で一般に流 通していないため、石膏ボード工業会が取得した国土交通大臣の認定を取 得した壁体構成を参考にして、厚さ $15 \mathrm{~mm}$ の強化せっこうボードを用いた。 注 4) 柱の損傷度が $100 \%$ となる断面二次モーメント $\left(\mathrm{I}=2.65 \times 10^{6} \mathrm{~mm}{ }^{4}\right)$ の算出 方法は、柱の有効細長比を 100 以上となる場合、次の通り、求められる。 実大試験時の載荷荷重 $\mathrm{N}$ は $\mathrm{N}=1.1 / 3 \times 3000 / \lambda 2 \times \mathrm{Fc} \times \mathrm{A}(\lambda$ :柱の有効細長比、 $\mathrm{Fc}$ : 基準強度 $\left(\mathrm{N} / \mathrm{mm}^{2}\right) 、 \mathrm{~A}$ : 試験前の断面積 $\left(\begin{array}{ll}\mathrm{mm} & 2\end{array}\right)$ ) と表され、 $\mathrm{N}=1.1 / 3 \times 3000 / \mathrm{L}^{2} \times \mathrm{Fc} \times \mathrm{Io}$ (L:座屈長さ $(\mathrm{mm}) 、 \mathrm{Io}$ 試験前の断面二次モーメント $\left.\left(\mathrm{mm}{ }^{4}\right)\right)$ と書ける。一方、座屈荷重 $\mathrm{P}$ は $\mathrm{P}=\pi^{2} \mathrm{EI} / \mathrm{L}^{2}\left(\mathrm{E}\right.$ :ヤング係数 $\left(\mathrm{N} / \mathrm{mm}{ }^{2}\right)$ 、 I:断面二次モーメント $\left.\left(\mathrm{mm}^{4}\right)\right)$ と表される。柱の損傷が進むとともに I が小さ くなると、座屈荷重 $\mathrm{P}$ も小さくなる。そこで $\mathrm{P}=\mathrm{N}$ となる $\mathrm{I}$ を求めると、 $\mathrm{I}=(1.1 / 3 \times 3000 \times \mathrm{Fc} \times \mathrm{Io}) /\left(\pi^{2} \mathrm{E}\right)$ と表され、I は L に依存しなくなる。值を代 入して $\mathrm{I}=1.1 / 3 \times 3000 \times 17.6 \times\left(1.013 \times 10^{7}\right) /\left(3.14^{2} \times 7.5 \times 10^{3}\right) \fallingdotseq 2.65 \times 10^{6}\left(\mathrm{~mm}^{4}\right)$ が 求められる。

注 5) 今回の $100^{\circ} \mathrm{C}$ 付近での温度停滞時間は、水上 ${ }^{16)}$ が CLT における検討結 果の中で示す実験值と比べると 1 ～2 分程度長くなったが、前報 ${ }^{1)}$ が合わせ てみると、せっこうボードの厚さにほぼ比例して長くなっており、概ね妥 当な結果であったと考えられる。

注 6) 計算值と試験結果が乘離した要因の考察として、計算值が加熱側面材 （内外装材）の熱伝導率を過小評価しており設定值が適切ではないと仮定 したが、加熱方向（屋外加熱・屋内加熱）を変えても、計算值が試験結果 より中空層温度が低くなるため、この仮定は当てはまらなかった。

注 7) 外装被覆に対し、層ごとに温度伝導率 $\alpha\left(\mathrm{m}^{2} / \mathrm{s}\right)$ 、壁厚 $\mathrm{d}(\mathrm{m})$ から熱貫通時 間 $\tau\left(=\mathrm{d}^{2} / \alpha, \mathrm{s}\right)$ として積算し、外装被覆の熱貫通時間を求め、加熱側柱角部 の温度が $260^{\circ} \mathrm{C}$ を超える時間との関係も検討したが、熱抵抗值で検討した 場合と概ね同様の傾向が得られたため、本文では熱抵抗值で議論を進めた。 


\title{
STUDY ON THE PREDICTION OF THE FIRE PROTECTION PERFORMANCE OF INSULATED WOODEN-WALLS BY SMALL-SCALE SPECIMENS
}

Predictability of quasi-fireproof performance of external wooden walls with rock-wool insulation

\author{
Osamu ITOGE* ${ }^{*}$ Yuji HASEMI**, Tsukasa TSUKIDATE*** \\ and Hirotaka SUZUKI*** \\ * Hokkaido Research Organization, Northern Regional Building Research Institute, M.Eng. \\ ** Prof., Dept. of Architecture, Waseda University, Dr.Eng. \\ *** Hokkaido Research Organization, Northern Regional Building Research Institute, Dr.Eng.
}

This study aims to establish the rational prediction of the fire protection performance of insulated wooden walls to reduce the full-scale fire tests. Series of small-scale furnace tests are conducted on various types of wall constructions with rock-wool insulation, the most stable practical insulation material.

The results of the fire tests and one-dimensional steady-state heat transfer calculation lead the following conclusion on the wooden insulated walls with rock-wool insulation.

Without cavity, the calculation can almost reproduce the temperature profile in the wall as the disadvantageous situation that temperature becomes higher in. And the engineering problems, to grasp the heat balance in cavity and to build calculation model of it, are left.

Fire protection performance is required flame insulation property, heat insulation property and non-damage ability in Japan's building standard act.

Heat insulation property can be predicted by checking thermal resistance. If insulated walls have thermal resistance bigger than $1.70 \mathrm{~m}^{2} \mathrm{~K} / \mathrm{W}$ when heated for 45 minutes, or $2.10 \mathrm{~m}^{2} \mathrm{~K} / \mathrm{W}$ when heated for 60 minutes, heat insulation property can be secured enough.

Heat insulation property is made a difference between when heated from indoor side and from outdoor side by cavity or the material which phase conversion happens in high temperature. In non-insulated wall, infilled insulated wall and additional insulated wall, heat insulation property become more disadvantageous when heated from indoor side than from outdoor side, with gypsum board as interior material. In addition, cavity acts on more advantageous against heat insulation property.

The time when combustion begins in the pillars depend on thermal resistance of external protection layer when heated from outdoor side, and depend on how long gypsum board delays temperature rise at around 100 degrees Celsius when heated from indoor side. Non-damage ability becomes more disadvantageous when heated from indoor side than from outdoor side in non-insulated wall and all insulated wall with rock-wool even if any constructing method.

The infilled insulation raises the back-surface temperature of the protection layer, also reduces the damage by protecting the side of the pillar. And the external insulation disturbs heat diffusion to the back side when heated from indoor side, also reduces the damage by protecting the front of the pillar when heated from outdoor side. Thus the infilled insulation and the external insulation have both advantageous factor and disadvantageous factor for non-damage ability. The combination of these factors can explain about non-damage ability in every constructing method of the insulated wall.

In addition, It is clarified that non-damage ability can be predicted by checking the back-surface temperature of the protection layer. This point suggests potential predictability by calculation, because the one-dimensional steady-state heat transfer calculation can almost reproduce the temperature profile, without cavity. 